Research Article

\title{
Progesterone Serum Level in-Labor Women does not Differ with not in-Labor Women
}

\section{Kadar Serum Progesteron pada Perempuan Inpartu tidak Berbeda dengan Kadar pada Perempuan yang tidak Inpartu}

\author{
Caroline Hutomo, Tjokorda GA Suwardewa \\ Department of Obstetrics dan Gynecology \\ Faculty of Medicine University of Udayana/ \\ Sanglah General Hospital \\ Denpasar
}

\begin{abstract}
Objectives: To find out the relation of serum progesterone level between patients in-labor and pregnant patients not in-labor.

Methods: This was an analytic cross-sectional study, comparing serum progesterone level between in-labor gravida and not in-labor gravida. Subjects were in-labor gravida $(n=21)$ and not in-labor gravida $(n=24)$ admitted to Sanglah Hospital from April to August 2011. The data were analyzed by SPSS 16.0. Independent sample ttest and Fisher's exact test were used.

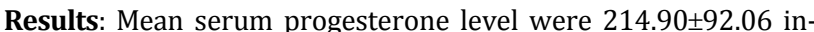
labor gravida and 190.69 \pm 76.02 not in-labor gravida $(t=0.966$ and $\mathrm{p}=0.399$ ).

Conclusions: There is no difference in serum progesterone level between in-labor and not in-labor pregnant women.

[Indones J Obstet Gynecol 2012; 36-4: 185-7]

Keywords: labor, progesterone, progesterone withdrawal
\end{abstract}

\begin{abstract}
Abstrak
Tujuan: Untuk mengetahui hubungan kadar serum progesteron dengan perempuan hamil inpartu dan tidak inpartu.

Metode: Dilakukan suatu penelitian cross sectional di mana dilakukan pengukuran kadar progesteron perempuan hamil, dibandingkan pada yang inpartu dan tidak inpartu. Kadar progesteron diukur pada $45 \mathrm{ibu}$ hamil dengan usia kehamilan > 28 minggu. Penelitian dilaksanakan di ruang bersalin dan poliklinik 108 bagian diperiksa Kebidanan dan Kandungan RSUP Sanglah Denpasar dari bulan April sampai bulan Agustus 2011. Kadar serum progesteron diperiksa di Laboratorium RSUP Sanglah. Data dianalisis dengan SPSS 16.0. Uji analisis yang digunakan adalah independent sample t-test dan Fisher'S Exact Test, dengan nilai $p<0,05$ dianggap bermakna secara statistik.

Hasil: Didapatkan rerata kadar serum progesteron kelompok inpartu

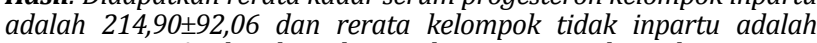
190,69 76,02. Analisis kemaknaan dengan uji t-independent menunjukkan bahwa nilai $t=0,966$ dan nilai $p=0,399$. Hal ini berarti bahwa rerata kadar serum progesteron pada kedua kelompok tidak berbeda $(p>0,05)$.

Kesimpulan: Berdasarkan hasil penelitian didapatkan simpulan sebagai berikut: Kadar serum progesteron perempuan hamil inpartu tidak berbeda bermakna dibandingkan dengan yang tidak inpartu.

[Maj Obstet Ginekol Indones 2012; 36-4: 185-7]

Kata kunci: inpartu, pelucutan progesteron, progesteron
\end{abstract}

Correspondence: Caroline Hutomo, Jln. K.S. Tubun no. 36, Jakarta 11420. Telephone: 08161693448,

Email: caroline.hutomo@yahoo.com

\section{INTRODUCTION}

The essential role of progesterone in the maintenance of pregnancy is already accepted. Its withdrawal is required to activate the myometrium, initiate labor and be a prerequisite of pregnancy termination. But the mechanisms that suppress progesterone's function to allow labor and delivery are still shrouded in uncertainty. ${ }^{1-4}$

In 1977, Csapo argued "if progesterone is indispensable in normal pregnancy maintenance, then progesterone withdrawal has to be a prerequisite of pregnancy termination".5-7
In 1994 Challis and Lye established that plasma progesterone level do not decrease before labor and decline only after delivery of the placenta. This apperent paradox has spawned the concept of "functional progesteron withdrawal". But the intimate mechanisms that underlie this key process of human parturition remain unknown. Based on the background, the purpose of this study is to find out the relation of serum progesterone level between in-labor gravida and not in-labor gravida. ${ }^{5-8}$ 


\section{METHOD}

A cross sectional analytic study with samples collected consecutively conducted from April 2011 to August 2011 at the obstetrics and gynecology emergency room and outpatient clinic of Sanglah General Hospital, Denpasar, Bali, Indonesia. The study population was pregnant women with gestational age above 28 weeks that check-up at Sanglah General Hospital. The requirement of the sample is minimum of 42 women, consisting of a minimum 21 in-labor gravida and 21 not in-labor gravida. All of the study sample are managed in accordance with the Obstetrics and Gynecology Department of the Udayana University/Sanglah General Hospital Denpasar guidelines therapy. The steps undertaken in this study were: anamnesis, physical examination, work-up diagnostic and examination of progesterone serum.

Examination of the serum progesterone was performed by drawing $5 \mathrm{cc}$ blood from the cubiti vein and inserting it into a plain tube. Plain tube was labeled with the patient's identity and the sequence number and then performed centrifugation $3,000 \mathrm{rpm}$ for $10 \mathrm{~min}$ to obtain the serum. Then the serum was diluted until $1 / 8$ of the concentration and then taken and inserted as much as 200 $\mu l$ to the container that has been provided in the kit of the Vidas Progesterone. Progesterone kit that has been filled with the serum sample is introduced into the machine from Biomerieux. Once processed it would automatically display the value of serum progesterone levels on the machine display. The value that appeared on the display screen is then multiplied by eight. This process was done at the Clinical Pathology of Sanglah General Hospital, Denpasar.

All statistical analysis were conducted on SPSS for windows $16^{\text {th }}$ version. Normality of the data was examined using the Shapiro Wilk test and the homogenity test using the Levene test. Comparability of the characteristics between in-labor gravida and not in-labor gravida using the ChiSquare test.

\section{RESULT}

Results obtained from 45 women who meet the inclusion and exclusion criteria, consisted of 21 inlabor gravida and 24 not in-labor gravida. Based on the analysis, we found there was a unsignificant differences between groups on the age, parity and abortion variables $(p>0.05)$. While on the gestational age variable there was significant difference $(p<0.05)$. The mean levels of serum progesterone for in-labor group was $214.90 \pm 92.06$ and not in-labor group was $190.69 \pm 76.02$. Analysis of significance with $\mathrm{t}$-independent test showed that the difference of mean serum progesterone levels in both groups was not significantly different ( $p>0.05)$.

Table 1. Subject Characteristic between Groups Variable age, parity, gestational age dan miscarriage history

\begin{tabular}{|c|c|c|c|c|c|}
\hline \multirow{2}{*}{ Variable } & \multicolumn{2}{|c|}{ In Labor } & \multicolumn{2}{|c|}{ Not In Labor } & \multirow{2}{*}{$\mathbf{p}$} \\
\hline & $\mathbf{n}$ & $(\%)$ & $\mathbf{n}$ & $(\%)$ & \\
\hline \multicolumn{6}{|l|}{ Age (yrs) } \\
\hline$<20$ & 0 & $(0.0)$ & 1 & $(4.2)$ & \\
\hline $20-35$ & 17 & $(81.0)$ & 19 & $(79.2)$ & 0.633 \\
\hline 35 & 4 & $(19.0)$ & 4 & $(16.7)$ & \\
\hline \multicolumn{6}{|l|}{ Parity } \\
\hline Nulipara & 13 & $(61.9)$ & 19 & $(79.2)$ & 0.202 \\
\hline Multipara & 8 & $(38.1)$ & 5 & $(20.8)$ & \\
\hline \multicolumn{6}{|c|}{ Gestational Age (wks) } \\
\hline$<37$ & 3 & $(14.3)$ & 11 & $(45.8)$ & 0.023 \\
\hline$\geq 37$ & 18 & $(85.7)$ & 13 & $(54.2)$ & \\
\hline \multicolumn{6}{|c|}{ Miscarriage History } \\
\hline 0 & 15 & (71.4) & 15 & $(71.4)$ & \\
\hline 1 & 4 & $(19.0)$ & 4 & $(19.0)$ & 0.195 \\
\hline 2 & 2 & ( 9.5$)$ & 2 & $(9.5)$ & \\
\hline
\end{tabular}

Table 2. Comparison of Serum Progesterone Level between in Labor and not in Labor

\begin{tabular}{lcccc}
\hline \hline \multicolumn{1}{c}{ Subject Group } & n & Mean & SD & p \\
\hline In Labor & 21 & 214.90 & 92.06 & \\
Not In Labor & 24 & 190.69 & 76.02 & 0.339 \\
\hline \hline
\end{tabular}

\section{DISCUSSION}

From the study, we found in significant differences between both groups on the age, parity and miscarriage history variable. This means that age, parity and miscarriage history variable has no effect on serum levels of progesterone, so that its influence is negligible.

But on gestational age variable there was significant difference between groups. On the gestational age variable less than 37 weeks, there were 3 people $(14.3 \%)$ in in-labor group and 11 people $(45.8 \%)$ in not in-labor group, whereas on gestational age greater than or equal to 37 weeks, there were 18 people $(85.7 \%)$ in in-labor group and 13 people $(54.2 \%)$ in not in-labor group. Based on the analysis, we found that both groups differ signifi- 
cantly $(\mathrm{p}<0.05)$. This is consistent with the theory in which the serum progesterone levels continue to rise and decline after the placenta is born. The older the mean gestational age, the higher the levels of serum progesterone.

The mean levels of progesterone serum in inlabor group was $214.90 \pm 92.06$ and in not in-labor group was $190.69 \pm 76.02$. Analysis of significance with t-independent test showed that the mean progesterone serum levels in both groups was not significant $(p>0.05)$. Progesterone serum levels did not differ in in-labor and not in-labor gravida. This fits with the Chaliss and Lye theory in 1994, which stated that plasma progesterone levels do not decrease before labor and decline only after delivery of the placenta.

The different is in the amount of progesterone receptors, instead of the serum progesterone levels. The fact that progesterone level do not fall at term in humans, raising the paradox as to how labor can occur under the continued influence of progesterone, which this has spawned the concept of functional progesterone withdrawal. Functional progesterone withdrawal theory states that human labor is not induced by the fall of systemic progesterone levels but by decreased progesterone receptors. 8,9

Functional progesterone withdrawal mediated by increased myometrial expression of PRA, in this case PRB is relatively decreased, where PRB mediates the progesterone action in the myometrium. Decrease in this receptor that could explain why the initiation of labor may occur despite serum progesterone levels remain high. Then Functional progesterone withdrawal induces functional estrogen activation by means of increased myometrial ERa expression. Functional estrogen activation with circulating estrogen increases CAP expression and uterotonin production that transform uterus to a contractile phenotype that will lead to the process of labor. 8,9

During human pregnancy, progesterone may not only suppress expression of CAP genes directly involved with myometrial contractility but also diminish the myometrial responsiveness of the myometrium to the estrogenic drive. This would explain why the myometrium is refractory to estrogenic drive for most of the pregnancy. Early in the parturition cascade myometrial PRA expres- sion increases leading to a decrease in genomicprogesterone responsiveness due to a repression of PRB transcriptional activity. The gradual inhibition of PRB mediated progesterone actions removes the inhibition of ERa expression leading to a concomitant increase in ERa expression levels, which would allow circulating estrogens to increase expression of CAP genes and transform the uterus to a contractile phenotype. ${ }^{8,9}$

\section{CONCLUSION AND SUGGESTION}

From this study it can be concluded that there is no significant difference in the serum progesterone between in-labor and not in-labor women. Further research is needed to investigate more about progesterone receptor (PR) and to find out whether the progesterone serum level does decrease in women who had delivered the placenta.

\section{REFERENCES}

1. Dong X, Shylnova O, Challis JR et al. Identification And Characterization Of The Protein-Associated Splicing Factor As A Negative Co-regulato Of The Progesterone Receptor. J Biol Chem 2005; 280(14):13329-40.

2. Merlino A, Welsh T. Nuclear Receptors In Human Pregnancy Myometrium: Evidence That Parturition Involves Functional Progesterone Withdrawal Mediated By Increased Expression Of Progesterone Receptor-A. J Clin Endocrinol Metab 2007; 92(5):1927-33.

3. Merlino A, Welsh T, Erdonmez T et al. Nuclear Progesterone Receptor Expression In The Human Fetal Membranes And Decidua At Term Before And After Labor. Reprod Scien 2009; 16(4):357-63.

4. Oh SY, Kim CJ. Progesterone Receptor Isoform (A/B) Ratio Of Human Fetal Membranes Increases During Term Parturition 2005; 193:1156-605.

5. Zakar T, Hertelendy F. Progesterone withdrawal: key to parturition. Am J Obstet Gynecol 2007; 196(4): 289-96.

6. Pieber D, Allport VC. Interactions Between Progesterone Receptor Isoforms In Myometrial Cells In Human Labour. Mol Hum Reprod 2001; 7(9):875-9.

7. Thijssen JHH. Progesterone Receptor In The Human Uterus And Their Possible Role In Parturition. J Steroid Biochemist Mol Biol. 2005; 97:397-400.

8. Mesiano S. The Endocrinology of Human Pregnancy and Fetoplacental Neuroendocrine Development. In: Strauss JF, Barbieri RL, eds. Yen and Jaffe's Reproductive Endocrinology Physiology, Pathophysiology, and Clinical Management. $6^{\text {th }}$ ed. Philadelphia: Saunders Elsevier. 2009; 249-81.

9. Mesiano S, Chan EC, Fitter JT et al. Progesterone Withdrawal and Estrogen Activation In Human Parturition Are Coordinated By Progesterone Receptor A Expression In The Myometrium. J Clin Endocrinol Metab 2002; 87(6):292430. 